INTERNATIONAL JOURNAL OF MULTIDISCIPLINARY RESEARCH AND ANALySis

ISSN(print): 2643-9840, ISSN(online): 2643-9875

Volume 05 Issue 03 March 2022

DOI: 10.47191/ijmra/v5-i3-03, Impact Factor: 6.072

Page No. 598-605

\title{
The Influence of Work Culture, Work Motivation, and Educational Supervision on PJOK Teacher Performance during the Covid-19 Pandemic
}

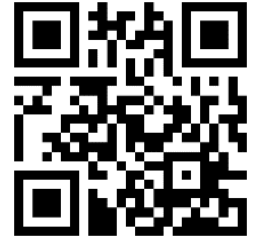

\author{
Dwi Murti Yadi ${ }^{1}$, Yudanto ${ }^{2}$, Amri Hartanto ${ }^{3}$, Betrix Teofa Perkasa Wibafiet Billy Yachsie ${ }^{4}$, Andrian Rahman Ayudi ${ }^{5}$, \\ Afeb Chesa Arianto ${ }^{6}$, Ujang Nurdin 7 , Gupo Matvayodha ${ }^{8}$ \\ $1,2,3,4,5,6,7,8$ Department of Sport Science, Yogyakarta State University, Yogyakarta Indonesia
}

ABSTRACT: The research objectives are to determine: (1) the influence of work culture on teacher performance; (2) the effect of work motivation on teacher performance; (3) the effect of educational supervision on teacher performance; and (4) the influence of work culture, work motivation, and educational supervision on the performance of PJOK teachers. This type of research is ex post facto. The population is PJOK teachers in SMA Negeri in Bantul Regency totaling 48 teachers, with a total sampling technique. The instrument uses a questionnaire via google forms. The data analysis technique is multiple regression analysis. The results showed that: (1) there was a significant influence between work cultures on the performance of PJOK teachers. (2) There is a significant influence between work motivations on the performance of PJOK teachers. (3) There is a significant effect between supervision on the performance of PJOK teachers. (4) There is a significant influence between work culture, work motivation, and educational supervision on teacher performance. The conclusion is that work culture, work motivation, and educational supervision have an effect on teacher performance.

KEYWORDS: work culture, work motivation, educational supervision, teacher performance

\section{INTRODUCTION}

The Covid-19 pandemic has hit all countries, including Indonesia. Currently, several campuses and schools are starting to implement policies for remote or online learning activities. Online learning is carried out because face-to-face learning is abolished to prevent the transmission of Covid-19. Currently, teachers are experiencing a changing role that requires new attitudes and efforts in carrying out learning methods in schools.

Physical activity is the main and dominant thing in learning Physical Education, Sports and Health (PJOK). The essence of PJOK learning, which requires physical movement, is that the learning is carried out in open spaces or in the field. The method for sports education is the deductive method or the command method, with various assignments, demonstrations and a little explanation (Supriyadi, 2018: 7). Therefore, the performance of teachers in the educational process should provide more practices to students directly through videos. However, when learning online, this cannot be done directly, it makes teacher performance not optimal. This can be seen from Bappenas data (Rismawan, 2015) states that the results of a survey conducted by UNESCO for the quality of teacher performance in Indonesia are at level 14 out of 14 developing countries. This shows that the teaching performance of teachers in Indonesia is still not in line with the ideals.

The low performance of teachers is also influenced by several things, including the current pandemic condition, learning is done online. Online learning is carried out by utilizing technology, especially the internet (Dai \& Lin, 2020), the use of internet networks that require costs (Jones \& Sharma, 2019; Purwanto et al., 2020). Many factors affect the teaching performance of teachers, namely motivation (Zuhriyah, 2015; Kasmir, 2016; Nellitawati, 2017; Ondima, 2014), organizational culture (Suharningsih, 2017), instructional supervision by school principals (Lyonga, 2018; Khan, 2014; Andriani, et al, 2018).

Teachers are the main implementation in the educational learning process to answer the need for quality human resources who can play a professional role in society. Therefore, the renewal of the educational process requires very high teacher performance. Teacher performance in schools is realized through the ability to educate, teach and train students in the learning process.

The performance of PJOK teachers really needs to be applied in the current new normal, especially in lesson planning, learning implementation and evaluation in learning. PJOK teachers as creators and motivators in the learning process, therefore teachers 


\section{The Influence of Work Culture, Work Motivation, and Educational Supervision on PJOK Teacher Performance during the Covid-19 Pandemic}

need to develop a learning atmosphere that is more attractive to students, so that students can express their interests and passions in learning, especially PJOK. The learning process that is managed with quality teacher performance will be able to produce quality human resources.

\section{METHODS}

This type of research is descriptive quantitative with an ex post facto approach. Ex post facto research is research that aims to find causes that allow changes in behavior, symptoms or phenomena caused by an event, behavior or things that cause changes in the independent variables which as a whole have occurred (Sukardi, 2015). This research was carried out in State Senior High Schools throughout Bantul Regency, which consisted of 19 schools. The research was carried out in January-February 2021.

The population is a generalization area consisting of: objects/subjects that have certain qualities and characteristics determined by researchers to be studied and then drawn conclusions (Sugiyono, 2015). Similarly, Arikunto (2013) states that "the population is the entire research subject". The population in this study were PJOK teachers at state high schools throughout Bantul Regency, which consisted of 19 schools with 48 PJOK teachers. The sample in this study was taken by total sampling.

Data collection tools used in the field, both data on work culture, teacher work motivation, supervision, and teacher performance in the form of a questionnaire/questionnaire. Questionnaires as a data collection tool are used because they can reveal facts according to the respondent's experience and the questionnaire is cooperative, respondents set aside time to answer questions in writing in accordance with the instructions given by the researcher (Arikunto, 2013). The instrument grid is presented in

Table 1:

Table 1. Instrument Grille

\begin{tabular}{|c|c|c|c|}
\hline \multirow{2}{*}{ Variable } & \multirow{2}{*}{ Indicator } & \multicolumn{2}{|l|}{ No Item } \\
\hline & & Positive & Negative \\
\hline \multirow[t]{2}{*}{ Work Culture } & Attitude towards work & $1,3,5,6,9,10,11,12,13,14$ & $2,4,7,8,15$ \\
\hline & Behavior at work & $16,18,20,21,22,24,25,26,27,28,29$ & $17,19,23,30$ \\
\hline \multirow{5}{*}{$\begin{array}{c}\text { Work } \\
\text { motivation }\end{array}$} & Achievement Needs & $1,2,4,6$ & 3,5 \\
\hline & Growth Opportunity & $7,8,9,10,12$ & 11 \\
\hline & The Job itself & $15,16,17,18$ & 13,14 \\
\hline & Need for recognition & $20,21,22,24$ & 19,23 \\
\hline & Wages & $26,27,28,29,30$ & 25 \\
\hline \multirow[t]{3}{*}{ Supervision } & Lesson planning & $1,2,3,4,7,10$ & $5,6,8,9$ \\
\hline & Implementation of learning & $13,14,15,16,17,18,19,20$ & 11,12 \\
\hline & Learning evaluation & $22,24,25,26,27,28,29,30$ & 21,23 \\
\hline \multirow{4}{*}{$\begin{array}{c}\text { Teacher } \\
\text { Performance }\end{array}$} & Making plans lesson & $2,4,5,6,7,8$ & 1,3 \\
\hline & Executing the plan lesson & $10,11,12,14,15,16$ & 9,13 \\
\hline & Carry out evaluation & $17,18,19,20,21,22$ & $20,23,24$ \\
\hline & Interpersonal relationship & $25,26,28,29,31,32$ & 27,30 \\
\hline
\end{tabular}

Data analysis technique is a process of simplifying data into a form that is easier to read and interpret. The data analysis used in this study were descriptive statistics, analytical prerequisite tests consisting of normality test and homogeneity test, and hypothesis testing such as multiple regression analysis, partial test ( $\mathrm{t}$ test), simultaneous test ( $\mathrm{F}$ test), and determination test (R2).

\section{RESEARCH RESULTS}

The results of the descriptive analysis are intended to determine the respondents' responses to the variables of work culture, work motivation, educational supervision, PJOK teacher performance in SMA Negeri in Bantul Regency based on the results of filling out questionnaires sent via google forms. The results are presented in Table 2:

Table 2. Descriptive Variable Statistics

\begin{tabular}{|l|l|l|l|l|l|}
\hline Variable & $\mathrm{N}$ & mean & SD & Min & Max \\
\hline Work Culture & 48 & 102.06 & 9.71 & 82.00 & 120.00 \\
\hline Work motivation & 48 & 103.85 & 9.17 & 84.00 & 117.00 \\
\hline Supervision & 48 & 102.25 & 10.60 & 75.00 & 119.00 \\
\hline Teacher Performance & 48 & 109.42 & 9.38 & 90.00 & 127.00 \\
\hline
\end{tabular}


The Influence of Work Culture, Work Motivation, and Educational Supervision on PJOK Teacher Performance during the Covid-19 Pandemic

\section{Normality test}

The normality test of the data in this study used the Shapiro-Wilk method. The summary of the analysis is presented in Table 3:

Table 3. Normality test

\begin{tabular}{|l|l|l|}
\hline Variable & $\mathrm{P}$ & Description \\
\hline Work Culture & 0.134 & Normal \\
\hline Work Motivation & 0.122 & Normal \\
\hline Supervision & 0.105 & Normal \\
\hline Teacher Performance & 0.111 & Normal \\
\hline
\end{tabular}

Based on Table 3 above, it shows that the variables of work culture, work motivation, educational supervision, and teacher performance obtained normality test results with a significance value of $p>0.05$, which means the data is normally distributed.

\section{Linearity test}

The linearity test of the relationship was carried out through the $\mathrm{F}$ test. Summary of the analysis The linearity test is presented in Table 4:

Table 4. Linearity Test

\begin{tabular}{|l|l|l|}
\hline Variable & $\mathrm{p}$ & Description \\
\hline Teacher Performance $*$ Work Culture & 0.091 & linear \\
\hline Teacher Performance $*$ Work Motivation & 0.310 & linear \\
\hline Teacher Performance * Supervision & 0.269 & linear \\
\hline
\end{tabular}

Based on Table 4 above, it can be seen that the significance value $(p)>0.05$. So, the relationship between the independent variable and the dependent variable is stated to be linear.

\section{Multiple Linear Regression Analysis}

Regression analysisdouble is used to test the independent variable together with the dependent variable. Based on the results of the analysis, it can be determined the multiple linear regression equation resulting from this study, as follows:

$$
\mathbf{Y}=\mathbf{9 . 7 7 9}+0.494 \times 1+0.325 \times 2+0.152 \times 3
$$

The constant is 9.779 , which means that if the variables of work culture, work motivation, and educational supervision are equal to zero, then the variable of teacher performance is only 9.779 .

\section{F Test (Simultaneous)}

$F$ test is a means of testing to determine whether the independent variables simultaneously (simultaneously) affect the dependent variable. The summary of the F-Test analysis is presented in Table 5:

Table 5. F Test Analysis Results (Simultaneous)

\begin{tabular}{|l|l|l|l|l|l|}
\hline Model & Sum of Squares & $\mathrm{df}$ & Mean Square & $\mathrm{F}$ & Sig. \\
\hline Regression & 3965.023 & 3 & 1321,674 & 348.97 & $0.000 \mathrm{a}$ \\
\hline Residual & 166,644 & 44 & 3,787 & & \\
\hline Total & 4131,667 & 47 & & & \\
\hline
\end{tabular}

Based on Table 5 above, the calculated F coefficient is $348.970>\mathrm{F}$ table 2.82, and the value of sig. $0.000<0.05$, then Ho is rejected, meaning. An alternative hypothesis which reads "There is a significant influence between work culture, work motivation, and educational supervision on the performance of PJOK teachers in SMA Negeri in Bantul Regency", accepted.

\section{T-Test Analysis Results (Partial)}

The t-test (partial) was conducted to determine the effect of work culture, work motivation, and educational supervision on the performance of PJOK teachers in SMA Negeri in Bantul Regency. The results of the t-test (partial) analysis are presented.

Table 6. T-Test Analysis Results (Partial)

\begin{tabular}{|l|l|l|l|r|r|}
\hline \multirow{2}{*}{ Model } & \multicolumn{2}{|l|}{ Unstandardized Coefficients } & Standardized Coefficients & \multirow{2}{*}{ S } & \multirow{2}{*}{ Sig. } \\
\cline { 2 - 4 } & $\mathrm{B}$ & Std. Error & Beta & & \\
\hline (Constant) & 9.779 & 3.308 & & 2,956 & .005 \\
\hline Work Culture & .494 & .118 & .511 & 4,200 & .000 \\
\hline Work motivation & .325 & .146 & .318 & 2.229 & .031 \\
\hline Supervision & .152 & .066 & 171 & 2,313 & .025 \\
\hline
\end{tabular}




\section{The Influence of Work Culture, Work Motivation, and Educational Supervision on PJOK Teacher Performance during the Covid-19 Pandemic}

The work culture variable has a t-count value of 4.200 and a significance value (sig) of 0.000 . Because the $t$ arithmetic value is $4.200>$ t table 2.013 and the significance value is $0.000<0.05$, then $\mathrm{HO}$ is rejected, meaning that Ha which reads "There is a significant influence between work culture on the performance of PJOK teachers in SMA Negeri in Bantul Regency" is accepted. The value is positive, meaning that if the work culture is getting better, then the performance of PJOK teachers in State Senior High Schools throughout Bantul Regency will also get better.

The work motivation variable has a t value of 2.229 and a significance value (sig) of 0.031 . Because the $t$ arithmetic value is $2.229>$ $\mathrm{t}$ table 2.013 and the significance value is $0.031<0.05$, then $\mathrm{HO}$ is rejected, meaning that Ha which reads "There is a significant influence between work motivation on the performance of PJOK teachers in SMA Negeri in Bantul Regency" is accepted. Positive value, meaning that if the work motivation is getting better, then the performance of PJOK teachers in State Senior High Schools throughout Bantul Regency will also get better.

The supervision variable obtained a t-count value of 2.313 and a significance value (sig) of 0.025 . Because the $t$ arithmetic value is $2.313>\mathrm{t}$ table 2.013 and the significance value is $0.025<0.05$, then $\mathrm{HO}$ is rejected, meaning that Ha which reads "There is a significant influence between work supervision on the performance of PJOK teachers in SMA Negeri in Bantul Regency" is accepted. Positive value, meaning that if the work motivation is getting better, then the performance of PJOK teachers in State Senior High Schools throughout Bantul Regency will also get better.

\section{Coefficient of Determination (R2)}

The coefficient of determination (R2) is essentially used to measure how far the regression model's ability to explain the variation of the dependent variable is. The results of the analysis are in Table 7:

Table 7. Results of the Analysis of the Coefficient of Determination (R2)

\begin{tabular}{|l|l|l|l|l|}
\hline Model & $\mathrm{R}$ & R Square & Adjusted R Square & Std. Error of the Estimate \\
\hline 1 & $0.980 \mathrm{a}$ & 0.960 & 0.957 & 1.94611 \\
\hline
\end{tabular}

The value of the coefficient of determination R Square or work culture, work motivation, and educational supervision in explaining or predicting the performance variables of PJOK teachers in SMA Negeri in Bantul Regency is 0.960 or $96.0 \%$. This means that the variables of work culture, work motivation, and educational supervision have an influence on the performance variable of PJOK teachers in SMA Negeri in Bantul Regency by $96.0 \%$, while the rest is influenced by other factors of $4.0 \%$ outside this study. Other variables that influence such as compensation, principal leadership, and others.

\section{DISCUSSION}

\section{The influence of work culture on the performance of PJOK teachers}

A high work culture will provide a strong impetus for teachers to work well which will result in maximum performance. Especially when the Covid-19 pandemic hit, teachers must have a higher work culture than before. According to Triatna (2015) "culture performs a number of functions within an organization." Culture is the social glue that helps unite the organization by providing appropriate standards for what employees should say and do.

In line with this research, organizational culture and motivation have a significant influence on teacher performance (Hutabarat, 2015). Another opinion states that to achieve performance, individuals must have the ability, motivation and have a good environment (Griffin \& Moorhead, 2014). Another study states that organizational culture affects teacher performance (Karantiano, 2018); Regards, et al. (2017); Susilawati (2018); Febrianta, et al. (2018); Hatemu, et al (2018); Lutfah, et al (2019); Ghanney et al (2017); Gunawan (2018): and Komarudin (2018), and there is a positive effect (Ismiyarto, et al., 2015), (Arifin, 2015) and a significant effect on teacher performance (Udin, et al., 2017). The higher the level of work culture that the teacher has, the higher the teacher's performance will be.

\section{The effect of work motivation on the performance of PJOK teachers}

The Covid-19 pandemic has resulted in learning being carried out online, so that in carrying out their professional duties, teachers are always obliged to develop professionalism in developing science and technology (Mandala \& Astika, 2019; Kawiana et al., 2018). This means that teachers are required to have high motivation. Motivation is an impulse that helps individuals to do or not do something in achieving goals. Motivation is a desire to achieve the desired task (Seebaluck \& Seegum, 2016; Dislen, 2016). Motivation plays an important role in school organization because it helps improve teacher skills (Ali, et al., 2016). High work motivation will provide a strong impetus for teachers to work well which can produce maximum performance, otherwise the low 


\section{The Influence of Work Culture, Work Motivation, and Educational Supervision on PJOK Teacher Performance during the Covid-19 Pandemic}

work motivation of teachers will reduce enthusiasm for work, so that teacher performance is not optimal. Teachers who have high work motivation will always work hard to overcome all kinds of problems faced in the hope of achieving better performance results. Komarudin's study (2018) that when work motivation increases, teacher performance will also increase. Kiruja \& Makuru (2013); Sokro (2016); Hamdani, et al (2018); Suryati, et al (2020); Abast, et al; (2018); Mine (2018); Djibu \& Duludu (2020); and Nzulwa (2014) which shows that motivation affects teacher performance.

\section{Supervision influenceon the performance of PJOK teachers}

Due to the Covid-19 pandemic, teacher performance has decreased, so the role of the principal as a leader is needed to always carry out evaluations. Supervision is an activity carried out by principals to assist teachers in developing their abilities and facilitating teachers in efforts to improve the learning process (Mulyasa, 2015). Supardi's research (2017); Ginting (2020) that supervision has an influence on teacher performance, the supervision carried out by school principals helps teachers in improving the quality of teacher performance so that the learning process activities are more optimal and of high quality. Ramadona \& Wibowo (2016); Imah (2018); Sudarsono (2017); Hasanah \& Kristiawan (2019) showed that the principal's supervision had an effect on teacher performance.

\section{The influence of work culture, work motivation, and supervision on the performance of PJOK teachers}

The work culture, work motivation, and supervision are getting better, the better the performance of PJOK teachers will also be. In line with the research of Joharis (2016); Marwan (2016); Nasrun \& Amabarita; Utami \& Wedasuwari (2019); and Nur (2015) that simultaneously the variables of organizational culture, work motivation, and supervision have a significant effect on teacher performance. Organizational culture is a factor that also influences teacher performance. A good culture will also have a good performance effect on teacher performance. Organizational climate or organizational culture is a set of characteristics of the work environment that is felt by workers either directly or indirectly (Yani, et al., 2017). On the other hand, work motivation has a positive impact on teacher performance. Thus it can be said that the better the work motivation of the teacher, the more motivated the teacher is in carrying out his duties well. With motivation, teachers will try to provide better services in carrying out their duties (Yani, et al., 2017). Supervision is one of the principal's duties in addition to being an administrator. Supervision management includes a series of activities starting from planning to evaluation, accompanied by follow-up on supervision activities. Principals have an important role in influencing teachers in schools. The principal can set various policies which if the policy is right, it will be able to improve the performance of teachers. One of these policies is supervision or control by the principal on teacher performance (Andriani, et al, 2018).

\section{CONCLUSIONS}

The conclusion of this study is that there is a significant influence between work cultures on the performance of PJOK teachers. There is a significant influence between work motivations on the performance of PJOK teachers. There is a significant influence between supervision on the performance of PJOK teachers. There is a significant influence between work culture, work motivation, and educational supervision on the performance of PJOK teachers. Simultaneously, the three variables, namely work culture, work motivation, and educational supervision, contributed significantly to teacher performance. Schools in which there is a good school culture, able to increase a sense of belonging, and responsibility, accompanied by teachers who have high work motivation and supervision are able to improve teacher performance.

\section{REFERENCES}

1) Abast, RM, Sangi, NM, Tumanduk, MSSS, \& Roring, R. (2018). Motivation, compensation, and performance for science and technological teachers. IOP Conference Series: Materials Science and Engineering, 306 (1).

2) Andriani, S., Kesumawati, N., \& Kristiawan, M. (2018). The influence of the transformational leadership and work motivation on teachers performance. International Journal of Scientific \& Technology Research, 7(7).

3) Apriana, D., Kristiawan, M., \& Wardiah, D. (2019). Headmaster's competency in preparing vocational school students for entrepreneurship. International Journal of Scientific \& Technology Research, 8(8).

4) Arifin, F. (2014). Organizational culture, transformational leadership, work engagement and teacher's performance: test of a model. International Journal of Education and Research, 2(1), 1-14.

5) Arikunto, S. (2013). Research procedure; a practical approach. (Revised edition) Jakarta: Rineka Cipta.

6) Dai, D., \& Lin, G. (2020). Online home study plan for postponed 2020 spring semester during the covid-19 epidemic: a case study of Tangquan Middle School in Nanjing, Jiangsu Province, China. SSRN Electronic Journal, 2(1).

https://doi.org/10.15354/bece.20.rp005/ 


\section{The Influence of Work Culture, Work Motivation, and Educational Supervision on PJOK Teacher Performance during}

the Covid-19 Pandemic

7) Dislen, G. (2016). The reasons of lack of motivation from the students and teachers voices. The Journal of Academic Social Science, 1(1), 35-45. https://DOI:10.16992/ASOS.13.

8) Djibu, R., \& Duludu, U. (2020). Impact of the work environment and work motivation in influencing the performance of non-formal educators. Journal of Nonformal Education, 6(1), 92- 100.https://doi.org/10.15294/ine.v6i1.24170.

9) Febrianta, S., Lutfiani, FN, \& Zein, N. (2018). The influence of organizational culture on teacher performance. Tadbir Muwahhid, 2(2).http://dx.doi.org/10.30997/itm.v2i2.1313.

10) Ghanney, RA, Antwi, T, A., \& Ali, H. (2017). School culture and teacher job performance: a comparative analysis of the perception of teaching staff in private and public basic schools in ga south municipality. British Journal of Education, 5(9), 108-121.

11) Ginting. (2020). Principal's supervisory function on teacher performance. Journal of Non-Formal Education, 1(2).

12) Griffin, RW, \& Moorhead, G. (2014). Organizational behavior: managing people and organizations. USA: Natorp Boulevard.

13) Gunawan, YM (2018). The influence of work culture and loyalty on the performance of elementary school teachers in Cibodas District. Journal of UMT Dynamics, 3(1).http://dx.doi.org/10.31000/dinamika.v3i1.1088.

14) Hamdani, Kesumawati, N., \& Kristiawan, M. (2018). The influence of teachers' work motivation and principals' managerial competence on teachers' performance. IOSR Journal of Humanities and Social Science (IOSR-JHSS), 23(9), 72-76. https:// DOI: 10.9790 / 0837-2309017276.

15) Hasanah, ML, \& Kristiawan, M. (2019). Academic supervision and how the teacher's performance. TADBIR: Journal of Educational Management Studies, 3(2).

16) Hatemu, Lian, B., \& Fitriani, Y. (2018). The influence of organizational culture, competency and teacher's certification toward teacher's performance. International Journal of Progressive Sciences and Technologies (IJPSAT), 20(1), 236246.http://dx.doi.org/10.52155/ijpsat.v20.1.1748.

17) Hutabarat, W. (2015). Investigation of teacher job-performance model organizational culture, work motivation and jobsatisfaction. Asian Social Science, 11(18), 295-304.

18) Imah, C. (2018). The influence of principal supervision on the performance of elementary school teachers in the Air Kumbang sub-district, Banyuasin Regency. Ad-Man-Pend, 1(2), 65-77.

19) Ismyarto, Suwitri, S., Warella, Y., \& Sundarso. (2015). Organizational culture, motivation, job satisfaction and performance of employes toward the implementation of internal bureaucracy reform in the ministry for the employment of state apparatus and bureaucracy reform. Journal of Management and Sustainability, 5(1), 192-199.

https://DOI:10.5539/jms.v5n1p192.

20) Jatmika, HM, Hariono, A., Purwanto, J., \& Setiawan, C. (2017). Analysis of the needs of physical education, sports and health teachers after the learning teacher program. Indonesian Journal of Physical Education, 12(1), 1-11. https://doi.org/10.21831/ipji.v13i1.21021.

21) Joharis, M. (2016). The effect of leadership, organizational culture, work motivation and job satisfaction on teacher organization commitment at senior high school in Medan. International Journal of Business and Management Invention, $5(10)$.

22) Jones, K., \& Sharma, R. (2019). On reimagining a future for online learning in the post-covid era.SSRN Electronic Journal,1(3). https://DOI:10.2139/ssrn.3578310.

23) Karantiano, S. (2013). The Influence of organizational culture, leadership behavior and job satisfaction towards teacher job performance. Indian Journal of Health and Welbeing, 4(9), 1637-1642.

24) cashmere. (2016). Human resource management (theory and practice). (Jakarta: PT. Rajagrafindo Persada.

25) Kawiana, IGP, Dewi, LKC, Martini, LKB, \& Suardana, IBR (2018). The influence of organizational culture, employee satisfaction, personality, and organizational commitment towards employee performance. International Research Journal of Management, IT and Social Sciences, 5(3), 35-45.

26) Khan, S. (2014). The supervisory role of the headmaster at the higher secondary level: a teacher's perception. Public Policy and Administration Research, 4(9).

27) Khasanah, U., Kristiawan, M., \& Tobari. (2019). The implementation of principals' academic supervision in improving teachers' professionalism in the state primary schools. International Journal of Scientific \& Technology Research, 8(8).http://dx.doi.org/10.31851/imksp.v5i2.3833.

28) Kiruja, EK, \& Makuru, E. (2013). Performance in public middle level technical training institutions In Kenya. International Journal of Advance Management and Economics, 2(4), 73-82. 


\section{The Influence of Work Culture, Work Motivation, and Educational Supervision on PJOK Teacher Performance during}

the Covid-19 Pandemic

29) Komarudin. (2018). The influence of work motivation and teacher work culture on the performance of State Vocational High School teachers in East Lampung. Journal of Lentera Pendidikan Research Center LPPM UM METRO, 3(1).

30) Lutfah, A., Hariyati, N., \& Handayaningrum, W. (2019). Improved teacher performance through work culture and environment. International Journal for Educational and Vocational Studies, 1(8), 859-863.

https://doi.org/10.29103/ijevs.v1i8.2240.

31) Lyonga, NAN (2018). Supervision and teachers' work performances in primary schools in Konye Sub-Division in Cameroon. Journal of Educational and Social Research, 8(2). https://Doi:10.2478/jesr-2018-0022.

32) Mandala, IGNAK, \& Astika, IBP (2019). Effect of work environment, quality of system and work culture on satisfaction of accounting information system user. International Research Journal of Management, IT and Social Sciences, 6(4), 37-43. https://doi.org/10.21744/irimis.v6n4.633.

33) Marwan. (2016). Effect of organizational culture, leadership behavior, achievement motivation, and job satisfaction on performance of lecturer at Private University in the Province of Aceh. IOSR Journal of Humanities and Social Science (IOSRJHSS), 21(II).

34) Mulyasa, E. (2015). Teaching evaluation principles and techniques. Bandung: PT Pemuda Rosdakarya.

35) Nadeem. (2017). Teacher's competencies and factors affect the performance of female teachers in Bahawalpur (Southern Punjab) Pakistan. International Journal of Business and Social Science, 2(19), 218.

36) Nasrun, \& Ambarita, DFP (2017). The effect of organizational culture and work motivation on teachers performance of public Senior High School in Tebing Tinggi. In 9th International Conference for Science Educators and Teachers (ICSET), 118, 320-26.https://doi.org/10.2991/icset-17.2017.53.

37) Nellitawati, N. (2017). Correlation between the role of principle with the pedagogical competences of teachers in Vocational School. COUNS-EDU: The International Journal of Counseling and Education, 5(2), 102-108. https://doi.org/10.29210/118200.

38) Nur, AH (2015). Employee job satisfaction and organizational performance: empirical study from higher education centers in Mogadishu Somalia. International Journal in Commerce, IT \& Social Science, 2(11).

39) Nzulwa, J. (2014). Motivational factors affecting high school teachers' professional conduct and work performance: a case of public high schools in Nairobi City. International Journal of Humanities and Social Science, 4(3).

40) Ondima, C. (2014). Effects of motivation on teacher's performance in Kenyan schools: a survey of Nya. Journal of Education and Practice, 5(30).

41) Purwanto, A., Pramono, R., Asbari, M., Santoso, PB, Wijayanti, LM, Hyun, CC, \& Putri, RS (2020). An exploratory study of the impact of the COVID-19 pandemic on the online learning process in elementary schools. Journal of Education, Psychology, and Counseling, 2, 1-12.

42) Ramadona, M., \& Wibowo, R. (2016). The effect of principal supervision on teacher performance at SMP K 1 Penabur Pasar Baru, Central Jakarta. Research and Development Journal of Education, $3(1)$.

https://DOI:http://dx.doi.org/10.30998/rdje.v3i1.1445.

43) Renata, R., Wardiah, D., \& Kristiawan, M. (2018). The influence of headmaster's supervision and achievement motivation on effective teachers. International Journal of Scientific \& Technology Research, 7(4).

https://www.researchgate.net/publication/326147101.

44) Salam, B., Ma'ufur, M., \& Laeli, S. (2017). The influence of work culture on the performance of certified teachers in Madrasah Aliyah. Tadbir Muwahhid, 1(1).

45) Seebaluck, AK, \& Seegum, TD (2016). Motivation among public primary school teachers in Mauritius. International Journal of Educational Management, 27(4), 446-464.

46) Sokro, E. (2012). Analysis of the relationship that exists between organizational culture, motivation and performance. Problems of Management, 3, 106-119.

47) Sudarsono. (2017). The influence of the supervision and leadership of the principal on the performance of teachers in SMA N 1 Dukuntang, Cirebon Regency. Scientific Journal of Islamic Studies, 2(1).

48) Sugiyono. (2015). Educational research methods approach quantitative, qualitative, and R \& D. Bandung: Alfabeta.

49) Suharningsih. (2017). Role of organizational culture on the performance of primary school teachers. Journal of Education and Learning, 6(1). https://DOI:10.5539/jel.v6n1p95.

50) hard. (2015). Education Evaluation. Jakarta: Earth Literacy.

51) Supardi. (2016). Teacher performance. Jakarta: Raja Grafindo Persada. 
The Influence of Work Culture, Work Motivation, and Educational Supervision on PJOK Teacher Performance during the Covid-19 Pandemic

52) Supardi. (2018). The effect of supervising madrasah principals in improving teacher performance. DIDACTICA STUDY: Scientific Journal of Education, 11(1).

53) Susilawati, S. (2018). The influence of organizational culture on teacher performance at SMA Negeri 6 Samarinda, Public Administration, 1(1).

54) Tamingan, HN (2018). The influence of principal leadership style and teacher work motivation on the performance of certified teachers at SMA Negeri Kotamobagu, North Sulawesi, Indonesia. Journal of Education and Learning (EduLearn), 12(3), 357-365.http://dx.doi.org/10.11591/edulearn.v12i3.8248.

55) Triatna, C. (2015). Organizational behavior in education. Bandung: PT. Rosdakarya Youth.

56) Utami, NMS, \& Wedasuwari, IAM (2019). Determinants of teacher performance and education power through work motivation, learning leadership, and organizational culture. International Journal of Sustainability, Education, and Global Creative Economics (IJSEGCE), 2(2).https://doi.org/10.1234/ijsegce.v3i1.85.

57) Winarni, S., \& Lismadiana. (2020). Competence of sports and health physical education teachers in terms of age and type of school. Indonesian Journal of Physical Education, 16(1), 101-114.

https://DOI:https://doi.org/10.21831/ipji.v16i1.29639.

58) Yani, A., Tunas, B., \& Entang, M. (2017). Transformational leadership, organizational climate and work motivation in boosting teachers' performance. International Journal of Managerial Studies and Research, 5(6), 43-50. https://doi:dx.doi.org/10.20431/2349-0349.0506006.

59) Zuhriyah, S. (2015). Factors that affect the performance of state vocational school teachers in tourism groups in the Special Region of Yogyakarta. LITERATURE, 6(2).http://dx.doi.org/10.21927/literasi.2015.6(2).203-215.

(C) $(1) \Theta$ There is an Open Access article, distributed under the term of the Creative Commons Attribution - Non Commercial 4.0 International (CC BY-NC 4.0)

(https://creativecommons.org/licenses/by-nc/4.0/), which permits remixing, adapting and building upon the work for non-commercial use, provided the original work is properly cited. 